\title{
Professional inclusion of young people affected by the human immunodeficiency virus in the Jiu Valley
}

\author{
Cosmin-Constantin Sicrea ${ }^{1}$, and Felicia Andrioni ${ }^{2, *}$ \\ ${ }^{1}$ University of Craiova, Faculty of Social Sciences, 13 A. I. Cuza Street, Craiova, Romania \\ ${ }^{2}$ University of Petroșani, Department of Socio-Human Sciences, 20 University Street, Petroșani, \\ Romania
}

\begin{abstract}
The background:The spread of the infection with the human immunodeficiency virus (HIV) globally and nationally among the population, mainly its young and adult segments, is a constant concern for various categories of specialists who analyse and seek solutions to reduce this phenomenon. HIV infection is not just a medical condition, but is a complex issue with social, psychological, educational, and economic implications for individuals and communities. Purpose: Identifying the level of professional inclusion of young people affected by HIV in the Jiu Valley. Method used: questionnaire-based survey. Results and conclusions: The existence of HIV diagnosis continues to be one of the main barriers in relation to the educational and professional path of young people in the studied community. The vast majority of the affected youth have experienced marginalization, discrimination and labelling. The educational and professional environment plays a particularly important role in the lives of young people affected by HIV, contributing to their involvement in an educational and professional process appropriate to their age, and to the growth of the degree of networking and socialization with others. The professional inclusion of young people affected by HIV is an essential step in the personal and professional development of youth.
\end{abstract}

\section{Analysis of the literature}

\subsection{Conceptual delimitations}

The HIV/AIDS pandemic has tremendously spread at a global level with serious implications upon population [1]. The Human Immunodeficiency Virus (HIV) is a highly virulent pathogen which attacks the cells of the immune system, multiplying inside them, weakening their ability to defend, then destroying them. Consequently, the body will not be able to fight infections or diseases. Although it has a rather primitive biological structure, the virus is not able to achieve its metabolism independently. For this he needs a host cell

\footnotetext{
* Corresponding author: feliciaandrioni@gmail.com
} 
that it invades and parasitizes. The main target of human immunodeficiency virus is constituted by the T4 cells (helper) on whose surface there is a protein called CD4.

The virus, once penetrated into the cell, multiplies inside it and then destroys it, being released into the blood ready to infect new cells. Initially the HIV infection is asymptomatic (primary infection). Over time, the body loses its ability to resist disease due to the declining number of $\mathrm{T} 4$ cells which, once infected, lose their function. Opportunistic infections are common in HIV-positive patients with a decrease in the number of T4 cells.

SIDA (Syndrome d'Immunodeficitaire Acquis) is the French abbreviation that defines the set of different diseases that specifically affect HIV-infected people who develop more or less severe immunodeficiency that leads to a series of opportunistic infections. SIDA / AIDS in English is not a single disease, it is an immunodeficiency syndrome.

SIDA / AIDS in English therefore means the stage in which the HIV infection leads to the compromise of the immune system characterized by treatment-resistant infections, confined to various organs or even the central nervous system. Most germs become highly pathogenic when the CD4 level of the HIV-infected person falls below 200 cells per cubic $\mathrm{cm}$ of blood. The most common opportunistic infections specific to this stage are: Candidiasis, Herpes, Kaposi's Sarcoma, Pneumonia (PPC), Tuberculosis, infections in the brain, etc. [2].

\subsection{The evolution of the HIV infection globally and nationally}

The HIV infection is still one of the hardest challenges for the international medical community. The first case of AIDS was reported in the United States in 1981 among homosexuals. Not knowing much about this condition, it was called the "homosexual disease." For the first time in 1983, Dr. Luc Montagnier isolated the human immunodeficiency virus (HIV) in the lymph nodes. Shortly after researchers established the first descriptions of the disease in adults, the first cases of AIDS in children appeared in the United States, and later on in Africa and Europe.

The disease appears to have been first diagnosed long before it appeared in the United States among homosexuals. In the 1960s, symptoms similar to HIV infection were found in some West African people who emigrated to Europe [3]. In 1983, the Centers of Disease Control reported in the "Morbidity and Mortality Weekly Report" five cases of severe pneumonia with Pneumocystis Carinii and Kaposi's sarcoma in young homosexuals with immune deficiencies [4]. In the following years, the US Centers for Disease Control and Prevention recorded 108 such cases, and specialized magazines talked about "homosexuals' cancer" and the "homosexuals' pneumonia".

At the beginning of 1990, the World Health Organization reported in Europe a number of 2120 cases of children infected with HIV, and approximately $50 \%$ of these cases were reported in Romania with 1094 recorded cases. In 1996, at the international conference held in Vancouver (Canada), the phenomenon acquired a scientific character of great interest, being presented 5380 papers on the phenomenon and reported approximately 28 million cases worldwide [5]. In 1998, the triple therapy was first introduced by combining three successful drugs. After its introduction, there was a decrease in viremia below the detectable threshold in patients treated with the new treatment regimen.

If at the beginning of 2002 women accounted for about $50 \%$ of the HIV infection cases worldwide, the year 2003 brought to the public a grim statistic announcing a number of 50 million people were infected with HIV and another 23 million lost their lives, the phenomenon being already in the attention of the medical community around the world [6].

According to data provided by UNAIDS, at the end of 2019 approximately 38 million people detected with HIV infection were living in the world, and 26 million had effective access to antiretroviral treatment. In 2019, approximately 1.7 million people became 
infected with HIV globally. Since the beginning of the HIV epidemic in the world, about 33 million people have lost their lives. Over $81 \%$ of HIV-positive people worldwide know their serological status, while it is estimated that over 7 million infected people do not know their diagnosis. This is quite worrying because in the absence of this information they can transmit the infection further without being recorded and implicitly not having access to antiretroviral therapy [7].

The targets mentioned by UNAIDS for 2020 internationally are: $90 \%$ of people worldwide to be tested for HIV, $90 \%$ of patients diagnosed to have access to treatment, $73 \%$ of people living with HIV to have a level of undetectable viral load (Figure 1) [8]. These goals of major interest to UNAIDS are in fact greatly slowed down by existing pressures in the global health system because of the SARS-COV2 pandemic.

\section{Fast Track Targets by 2020}

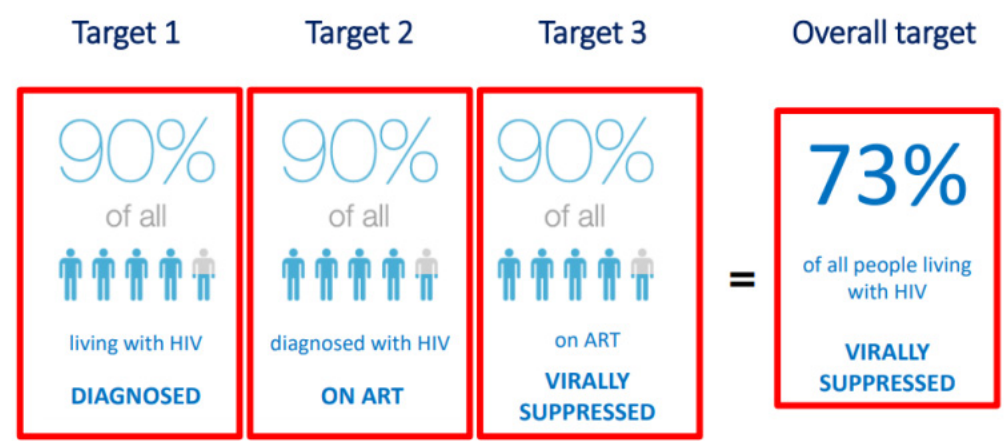

Fig. 1. UNAIDS targets for 2020 in relation to global HIV infection. Source:UNAIDS, 2020 [9].

The evolution of antiretroviral therapies on the international market is felt by the existence of several drugs capable of suppressing viral replication and the growth of CD4 cells responsible for the individual's immunity. Thus, starting with 2017, according to the National Drugs Agency, we also find new generation drugs in our country capable of suppressing viral replication by administering a safe dose (one tablet) / day, according to the evaluation reports of medical technologies within the National Drugs Agency[10]. The evolution of HIV infection as well as the fight against it in our country belongs to the National Commission for the Fight against AIDS within the Institute of Infectious Diseases "Matei Balş" of Bucharest. In addition to this goal, CNLAS aims to improve access to antiretroviral therapy to all recorded patients. Another particularly important aspect is the importance of modernizing the IT network by setting up a system that allows real-time communication with all regional centres.

The data obtained from the regional centres for the evaluation and monitoring of the HIV infection are further processed within the department for monitoring and evaluation of HIV / AIDS infection in Romania.

According to the latest CNLAS statistics, in Romania in the year 2020 in the official data there were a number of 16,848 patients alive on 31.12.2020. As for the access to antiretroviral medication at the end of 2020, a number of 12,971 people affected by HIV or AIDS were being treated, while 111 lost their lives. As regards the new cases detected during the same year, 432 persons were recorded [11]. 


\subsection{Psycho-social and educational implications of the HIV infection}

Society's response to the HIV infection can be seen as a permanent oscillation between supporting and rejecting people living with HIV. It is very difficult for people affected by HIV / AIDS or their family to "fight", both with the disease, but especially with society.

„The fight against the disease" is sometimes seen as an acceptance of the situation but also a permanent confrontation at the psychosocial level. Among the psychosocial aspects we can highlight those related to the disease (limitation of physical capacity, limitation of professional or family responsibilities), rejection from the family or group in the community of origin, loss of friends, limitation of access to educational, medical or social services.

The vast majority of the young people infected who have experienced marginalization, discrimination and labelling have gradually developed a degree of dependence on the family environment that counterbalances the lack of social support. In many cases, once the diagnosis of HIV infection is revealed, the HIV-positive youth becomes a marginal member or even a former member of the group (fellow friends) of which he or she belongs.

The attitude of health educators is essential for the good information so that prejudices towards infected people are reshaped to appropriate behavioural patterns. We therefore arrive at the concept of normalization of HIV-positive young people and adolescents through non-discriminatory participation in the social life [12]. The social work services are meant to provide support and social protection to both the HIV-positive young person and his family. This requires a professional approach from an ethical and methodological point of view, but also a mobilization of community resources to prevent school dropout [2].

School dropout is one of the most visible effects of the HIV / AIDS epidemic in our country. There are multiple causes underlying school dropout among HIV-positive young people in Romania [3], namely: a) the attitude of exclusion manifested by the school, class or community; b) self-exclusion form schooling- many parents have withdrawn their children in the past from school for fear of disclosing the diagnosis in school and community; c) long periods of hospitalization - young people who have been hospitalized for long periods of time have often failed to recover lost hours and related requirements; $d$ ) the school community is facing such a case for the first time or there is little authentic information about HIV infection; e) communicating the diagnosis of some uninformed persons who did not respect the confidentiality of the case; f) the family fails to realistically identify the situations in which the child needs a special care regime, becoming hyperprotective by withdrawing the adolescent from school; g) the disease becomes a primary event and all the other needs of the HIV-positive young person (education, socialization, social involvement) are ignored.

In order to overcome these discriminatory situations, HIV-positive young people try to enrol in other schools in the community without revealing their diagnosis.

The existence of a limited number of educational programs accessible to the HIVpositive youth at school age makes it difficult to access a differential education.

According to estimates, approximately $20 \%$ of the HIV-positive young people attending compulsory education are integrated into special schools precisely because of the diagnosis and not because of the cognitive-behavioural abilities [13].

The exclusion of the HIV-infected young person from the educational environment may be the beginning of a family crisis. Often the family is overwhelmed by feelings of confusion and requires the intervention of a social worker. The latter must recognize the individuality and strength of the family and respect the ways in which the family copes with the situation. The role of the social worker in this case is to facilitate the social network and support the family. 


\section{Research methodology. Data analysis and interpretation}

The purpose of the research aimed at identifying the level of professional inclusion of the youth affected by HIV in the Jiu Valley, Hunedoara County.

The hypothesis from which the research started was the following: "the existence of the HIV infection has a negative impact upon the educational and professional path, if the diagnosis is made known in the educational or professional environment". The research method used was the direct questionnaire-based sociological survey. The study group consisted of 43 subjects affected by HIV who were selected based on the snowball technique through the informal social network of specialized staff, patients with whom there has been a collaboration in the past in health education projects or patients of certain groups, informal therapy and support.

From the level of education viewpoint, the situation of the 43 respondents of the survey is as follows (Table 1):

Table 1. Level of education.

\begin{tabular}{|c|c|c|c|c|c|}
\hline Variants & $\begin{array}{c}\text { Middle } \\
\text { school }\end{array}$ & $\begin{array}{c}\text { Secondary } \\
\text { school } \\
\text { (vocational / } \\
\text { high school / } \\
\text { post- } \\
\text { Subjects }\end{array}$ & $\begin{array}{c}\text { Higher } \\
\text { education }\end{array}$ & $\begin{array}{c}\text { Post- } \\
\text { graduate } \\
\text { studies }\end{array}$ & $\begin{array}{c}\text { Total } \\
\text { Subjects }\end{array}$ \\
\hline & $25.60 \%$ & $62.80 \%$ & $11.60 \%$ & $0.00 \%$ & $43(100 \%)$ \\
\hline
\end{tabular}

Over $62 \%$ of respondents say they are graduates of secondary education (high school or vocational), while a fairly small number of $11.60 \%$ have completed some form of higher education.

As regards their current socio-professional status according to the table below, two categories of subjects were identified as disabled by the disability certificates issued by DGASPC Hunedoara, respectively as retired persons included in a degree of disability by Casa Hunedoara County Pension.

Based on the data collected with the method of sociological survey, it was found that a very low number of respondents are currently employed $(4.65 \%)$ or attend the courses of pre-academic or higher educational institutions (4.65\%).

Table 2. Current socio-professional status.

\begin{tabular}{|c|c|c|c|c|c|}
\hline Variants & $\begin{array}{c}\text { School pupil } \\
\text { / Student }\end{array}$ & Employee & $\begin{array}{c}\text { Person with } \\
\text { handicap }\end{array}$ & $\begin{array}{c}\text { Retired } \\
\text { (invalidity) }\end{array}$ & $\begin{array}{c}\text { Total } \\
\text { Subjects }\end{array}$ \\
\hline & 4.65 & 4.65 & 48.85 & 41.85 & $43(100 \%)$ \\
\hline
\end{tabular}

As per Law 584 of 2002, a law that defends the rights of HIV-positive people in Romania, Article 3 stipulates that "the persons infected with HIV or diagnosed with AIDS benefit from social protection, non-discriminatory treatment in terms of the right to education, the right to work and social protection of work and professional promotion, and their state of health cannot be a criterion for dismissal" [14].

As we can see in the text of this law, HIV-positive people can benefit from social protection, the right to education and professional promotion. Moreover, Law no. 448 of 2006, republished in 2008, regarding the protection of persons with disabilities in art. 3 (d) guarantees "equal treatment as regards employment and occupation" [15].

Thus, at least from a legislative point of view, HIV-positive people enjoy protection from the state when it comes to access to education, training and employment. Starting from these rights stipulated in the aforementioned laws, we investigated the employment 
segment and whether the access to the labour market is really realised. According to the results obtained, we can see that over $32 \%$ of them have not actually searched for a job so far either due to lack of qualification due to early school leaving, or fear of not being rejected.

Just over 30\% said they encountered obstacles whenever they tried to find a job, hitting employers' refusals. The refusal followed the documents in the employment file, including the medical history of HIV infection.

Of the persons surveyed, over $23 \%$ said they are not currently employed and are not looking for a job. In the absence of viable alternatives, the Romanian state tends to compensate for these shortcomings by providing social benefits in cash (Figure 2).

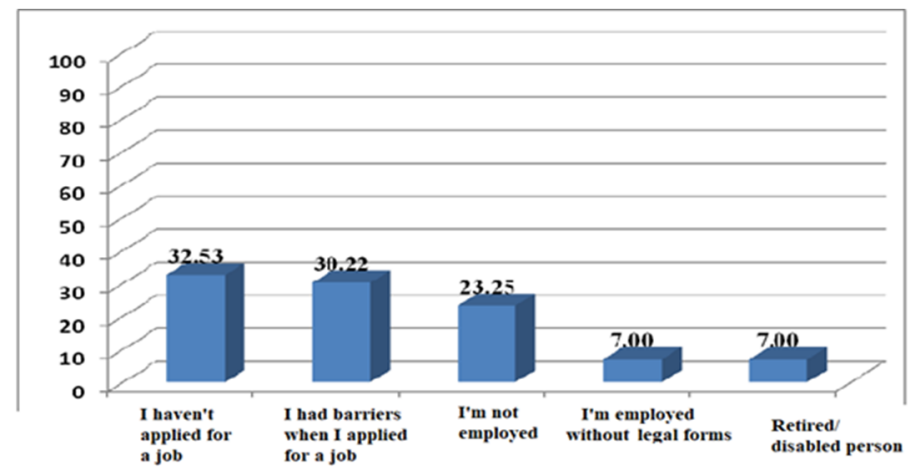

Fig. 2. Difficulties caused by diagnosis in identifying a job (\%).

Despite the obstacles encountered, only $7 \%$ of the interviewed youth say that they currently have a job but without legal forms, precisely to avoid legislative gaps regarding discrimination in relation to HIV / AIDS at work.

Moreover, $7 \%$ of the subjects also stated that they are currently classified as disabled (persons with handicap), while other subjects also benefit from retirement in the degree of disability, the so-called "sickness pension", the two incomes can be combined. According to the GD 257/2011, which regulates the application norms for Law 263/2010 on the unitary public pensions system in Romania, in art. 57, letter a) we remark that "the invalidity pension is granted, regardless of the contribution period completed: a ) to persons who have lost all or at least half of their ability to work due to accidents at work and occupational diseases according to the law, neoplasms, schizophrenia and AIDS "[16]. This will be regulated in the new pension law where the principle of non-contributory in case of schizophrenia and HIV / AIDS will be removed from the text of the law. On the other hand, according to the regulations in force, the employment of a person is possible taking into account the legislative requirements in force. Also, the GD no. 355/2007 regulates "the surveillance of the workers' health against the risks for safety and health, for the prevention of the sickness of the workers with occupational diseases caused by harmful chemical, physical, physic-chemical or biological agents, characteristics of the workplace, as well as the overload of different organs or systems of their organism in the work process" (as per art.1) [17]. The medical examination on the moment of employment is part, according to art. 8, para. (1), of the above-mentioned Government Decision, from the prophylactic medical services through which the supervision of the employees' health is ensured, along with the periodical adaptation medical examination, the check-up on the activity resumption, and the special supervision and health promotion at the place of work.

Starting from the purely legislative approach to medical examinations on employment, the subjects were asked to express their opinion on HIV testing, regardless of the field 
concerned, taking into account the socially shaped image of people affected by HIV / AIDS (Figure 3).

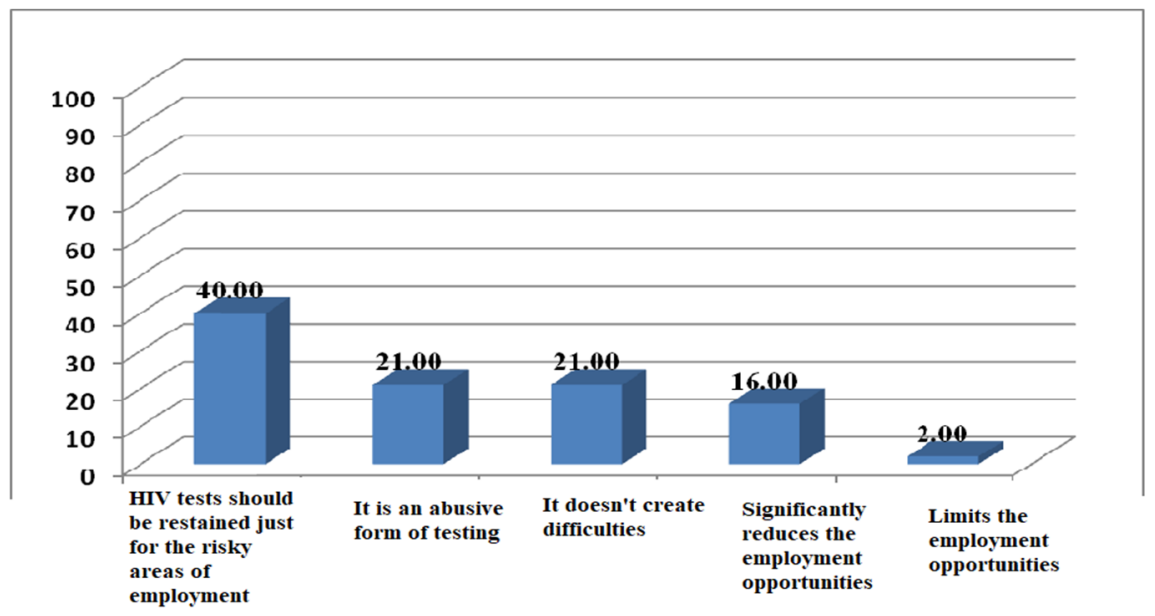

Fig. 3. Respondents' perception on the ,mandatory" HIV testing on employment (\%).

Most of the respondents, namely $40 \%$, believe that HIV testing on the moment of employment should be restricted only in areas considered at risk and only where the law expressly requires it. They are of the opinion that the concept of "mandatory testing" should exist only under the conditions established by law.

HIV testing on employment continues to be an "abusive form of testing" for $21 \%$ of young participants in the study, while $21 \%$ believe this is not an impediment to practicing a profession.

When it comes to the introduction of HIV testing on employment, $16 \%$ of subjects believe that once the HIV-positive serological status is highlighted, the chances of integration into the labour market are significantly reduced, and employers are not yet ready to accept and get employed of people. On the other hand, in the opinion of only $2 \%$ of those surveyed, HIV testing drastically conditions employment once the diagnosis is found.

The existence of an illness can influence the choice of career path both physically and psychologically (feeling of helplessness).

The difficulty in choosing a profession continues to be one of the problems characteristic to HIV-positive persons in Romania. In this respect, taking into account the probability of HIV testing on employment, the respondents were asked whether the existence of the disease influences the career path, and most respondents thought that disclosure of the diagnosis generates difficulties in choosing the profession. So the main problem remains the difficulty of choosing a profession, a little over $60 \%$ being in this risk situation (Figure 4). The barrier raised by the finding of the diagnosis continues to be the main cause of discrimination at the workplace.

About $28 \%$ of the respondents believe that, despite the diagnosis, the career path is not influenced, at least not visibly. The latter believe that the limitations given by the disease do not prevent them from having their own professional path considering that they are ordinary people.

Around $9 \%$ of participants considered that the choice of a profession involves a relative degree of difficulty, the limits being given rather by the professions considered at risk where accidental exposure to blood is increased, the limitation being rather legislative when 
imposing certain obstacles. They believe that the existence of the infection does not build walls when there is a desire to choose a profession.

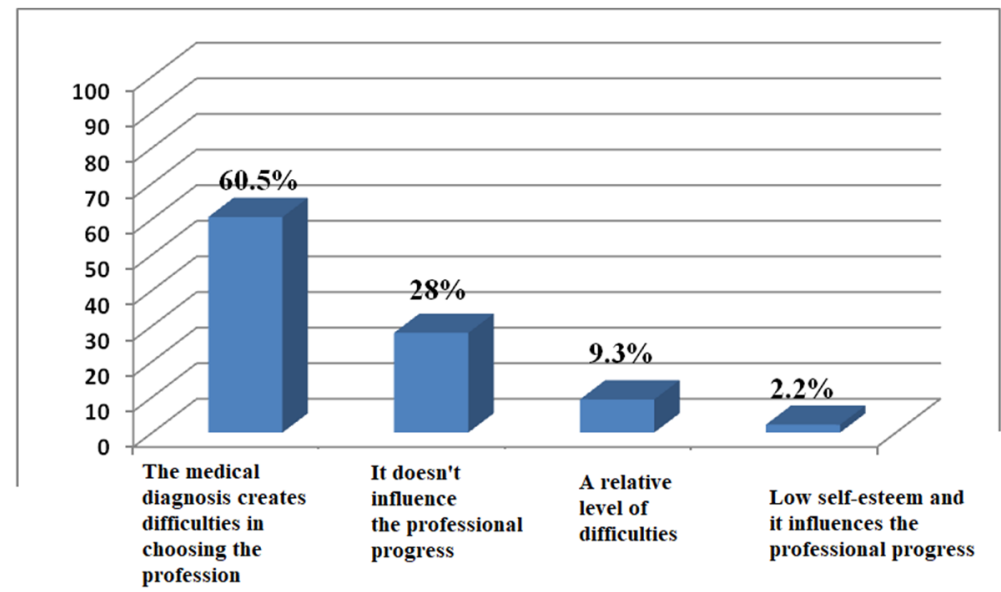

Fig. 4 The influence of the diagnosis on the professional path (\%).

A relatively low percentage of about $2 \%$ of the subjects stated that the existence of the disease creates a psychological pressure characterized by decreased self-esteem and directly influencing their training and integration on the labour market.

An imported part of Romanian employers are not prepared to have HIV-positive employees, in the sense that they do not have enough information on this issue, do not know the legal provisions for people with disabilities and have not established procedures for the situation where a person with disabilities is discriminated against at the place of work.

Based on these considerations, the subjects were asked to imagine a meeting with a potential employer.

They were asked about how HIV-positive people are viewed by employers when they apply for a job interview and find out about their health. Most respondents, over 34\%, believe that employers are not prepared to accept HIV-infected people into their company despite the fact that they may have the required qualifications and skills. The fear of their infecting other employees and the risk of discrediting the company make many employers reluctant to be HIV-positive candidates. This happens even in the context where the organizations that defend and promote the rights of people affected by HIV / AIDS in our country, periodically organize thematic seminars and round tables with representatives of employers in Romania. In this respect, the promoter of these initiatives at national or regional level is UNOPA under the auspices of which 24, HIV / AIDS associations, regularly organize such workshops. Although organized regularly, after attending them employers agree to integrate people affected by HIV / AIDS only on the declarative level. In UNOPA's view, the number of employees in reality is still very low, with an "enormous discrepancy between the willingness to hire HIV-positive people in contrast to the actual number of HIV-positive employees, which in Romania is currently 54: 1" [18]. Another situation identified in the study concerns the category of young people who did not go at any job interview due to the diagnosis. Thus, a part of the young participants in the study, respectively $28 \%$ stated that due to the diagnosis, so far they have not faced this situation, and have not gone to any job interview. This can also be generated by poor schooling, as approximately $62 \%$ of respondents are graduates of secondary education, generally vocational (10 grades) in special schools. 


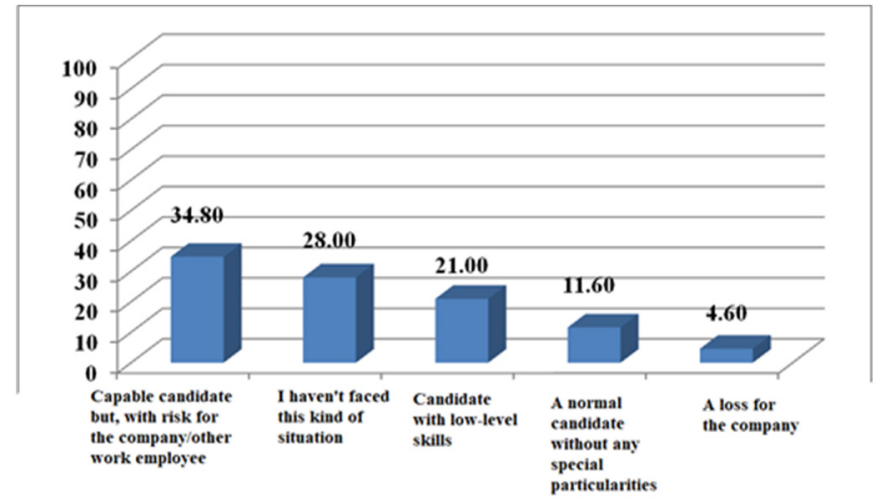

Fig. 5. How an employer would look at an HIV-positive candidate (\%).

Self-esteem continues to be quite low for $21 \%$ of subjects, who believe that employers view them as candidates with low abilities and skills, which disqualifies them from being able to perform paid work. They say employers generally view the HIV-infected as limited in their abilities to work and as becoming a burden on the company.

A particular case in this direction caught our attention when we had discussions with a young man who stated that when he wanted to work as a bread delivery driver, the employer fired him 2 days after finding out the diagnosis on the grounds that "he cannot drive a bread delivery van if he is infected with HIV". This shows that although the transport and handling of bread crates does not involve the risk of illness for others, the employer was not willing to keep an HIV-positive driver in the company.

A rather low percentage, just over $11 \%$ of the respondents, believe that an HIV-positive person can successfully represent the usual candidate without special features. In their opinion, HIV-positive persons should not be limited due to the diagnosis as long as they have the necessary qualifications and their health allows them to work. On the other hand, over $4 \%$ of the respondents continue to believe that the person affected by HIV / AIDS is a liability for the company and employers do not want to render their efforts within the company more difficult.

\section{Conclusions}

The existence of an HIV-positive diagnosis continues to be the main barrier in the way of shaping the educational and professional path of the HIV-positive young person from the Jiu Valley. Disclosure of the diagnosis in school or at the work place has increased the risk of social exclusion of young people affected by HIV.

Due to the lack of alternatives in relation to earning income by performing legally paid work, some of the respondents choose to work without legal papers. Medical examination on the moment of employment and disclosure of a positive HIV diagnosis through certificates issued by family doctors continues to be the main source of breach of confidentiality.

Disclosing the diagnosis professionally can affect the social life of the HIV-positive patient, especially in small communities. The lack of alternatives with an inclusive role leads to the creation of a dependence on the social protection system and implicitly on social benefits, most of the HIV-positive young people being classified as persons with handicap or disabled pensioners. This only discourages socio-professional inclusion in an active, practical way. 
The schooling of the HIV-positive youth is deficient, many of them completing compulsory or vocational education in a special school, at the recommendations of those qualified at that time regardless of cognitive abilities, the criterion of HIV-positive being defining in this case.

Consequently we can say that the hypothesis according to which ,, The existence of HIV infection has a negative impact on the educational and professional path if the diagnosis is made known in the educational or professional environment" is fully confirmed.

Employers continue to be reluctant when it comes to integrating an HIV-positive young person into work. The lack of inclusive programs in a professional context makes more and more HIV-positive young people give up their efforts of getting integrated into the labour market.

\section{References}

1. F. Andrioni, Trends of HIV/AIDS Phenomenon Dynamics in Romania from 2017-2027 Iran. J. Public Health, 48 (10), 1903-1909. (2018) https://doi.org/10.18502/ijph.v48i10.3499

2. F. Ignat (coord), Bulancea P., The role of school in preventing the transmission of HIV infection and the school integration of the youth living with HIV / AIDS (in original in Romanian), MarLink Publishing House, Bucharest (2006)

3. M. Iftimoaei, HIV / AIDS between justice and normalcy (in original in Romanian), Alături de Voi Foundation, Iaşi (2007)

4. Centers of Disease Control, Morbidity and Mortality Weekly Report, Atlanta, Georgia (1986)

5. D. Buzducea, AIDS psychosocial confluences (in original in Romanian), Science and Technics Publishing House, Bucharest (1997)

6. F. Andrioni (coord)., Information, counselling and career guidance for people affected by the human immunodeficiency virus. Good practice guide (in original in Romanian), Corvin Publishing House, Deva (2011)

7. UNAIDS, Facts Sheet- World AIDS day Global HIV Statistics, 2019, accessed online at: https://www.unaids.org/sites/default/files/media_asset/UNAIDS_FactSheet_en.pdf accessed on 16.02.2021

8. UNAIDS, Facts Sheet- World AIDS day Global HIV Statistics, accessed online at: https://www.unaids.org/sites/default/files/media_asset/UNAIDS_FactSheet_en.pdf 2021

9. UNAIDS, 90-90-90: A Ambitious Treatment Target To Help End The Aids Epidemic, accessed online at: https://www.unaids.org/en/resources/909090, accessed on 10.02.2021

10. Ministry of Health, National Drugs Agency, DCI Medical Technology Assessment Report Combinations (Emtricitabinum + Tenofovirum) Indication in combination with other antiretroviral medicinal products for the treatment of adults and adolescents infected with human immunodeficiency virus type 1" (in original in Romanian), accessed online at: https://www.anm.ro/_EVALUARE\%20TEHNOLOGII\%20MEDICALE/28303_Combina\%c8\% 9bii\%20(Emtricitabinum+Tenofovirum)_Descovy\%20200\%20mg+10\%20mg.pdf accessed on $8.02 / 2021$

11. National Commission for the Fight against AIDS - Institute of Infectious Diseases Prof. Dr. Matei Balş, Department for Monitoring and Evaluation of HIV / AIDS Infection in Romania, The evolution of HIV / AIDS infection in Romania December 31, 2020 (in original in Romanian), accessed online http://cnlas.ro/images/doc/31122020_rom.pdf, accessed on 04.02.2021

12. D. M., Chirilă, Prevention of HIV / AIDS, other sexually transmitted infections and drug use (in original in Romanian), Speed Promotion Publishing House, Bucharest (2006)

13. Human Rights Watch, Life does not wait. Romania's failure to protect and support children and young people living with HIV (in original in Romanian), 18 (6 D), (2006)

14. The Parliament of Romania, Law no. 584 of 29 October 2002 on measures to prevent the spread of AIDS in Romania and to protect people infected with HIV or AIDS (in original in Romanian), (2002)

15. The Parliament of Romania, Law no. 448/2006 republished in 2008 with subsequent alterations, on the protection of persons with handicap (in original in Romanian), accessed online at : 
http://www.dreptonline.ro/legislatie/lege_protectia_persoane_handicap_448_2006_rep_2008.php , la data de 24.01.2021

16. The Government of Romania, Government Decision no. 257/2011 for the approval of the application norms for the provisions of Law no. 263/2010 on the unitary public pensions system
(in origina
in
Romanian),
accessed
online
at:

http://www.dreptonline.ro/legislatie/hg_257_2011_aprobare_norme_legea_263_2010_sistemul_u nitar_de_pensii_publice.php accessed on 11.01.2021

17. The Government of Romania, Government Decision no. 355/2007 on the supervision of employees' health (in original in Romanian), accessed online at: https://lege5.ro/Gratuit/geydkojqga/hotararea-nr-355-2007-privind-supravegherea-sanatatiilucratorilor, accessed on 11.02.2021

18. National Union of the Organizations of People Affected by HIV / AIDS (UNOPA) National HIV / AIDS Conference and the Workplace (in original in Romanian), accessed online at: https://unopa.ro/conferinta-nationala-hivsida-si-locul-de-munca/, (2008), accessed on 9.01.2021 